\title{
INFLUENCE OF TYPE OF PRE-HAIR TREATMENT FROM DIFFERENT TYPES OF ANIMAL SOURCES ON THE DEGREE OF HYDROLYSIS OF KERATIN
}

\author{
DARINA ZHELEVA, MARGARITA KOLEVA \\ University of Chemical Technology and Metallurgy, Department of Textile and Leather, Sofia, \\ Bulgaria; e-mail: darinajeleva@abv.bg
}

\begin{abstract}
Keratin biomaterials have many different advantages over other biomolecules. A number of techniques have been studied to prepare keratin hydrolysates. Many of them use strong reagents and the processes take place under very drastic conditions. The present study focuses on the following aspects: producing keratin hydrolysates from various animal sources; application of various methods for extraction; comparison of the type of treatment over the degree of hydrolysis. Sheep wool samples were used, respectively native and alkaline pre-treated and samples of goat hair, respectively native and enzyme pre-treated. The methods used for the hydrolysis of keratin materials are: 1) by sulfotolysis with sodium pyrosulfate and urea; 2) with thioglycolic acid and 3) with sodium hydroxide. The obtained hydrolysates were characterized by qualitative reactions, spectrophotometric and FTIR analysis. It was found that the samples from one and the same animal source show very different properties and different degrees of hydrolysis. The highest degree of hydrolysis was achieved for the pre-treated samples. It was proved that the method of hydrolysis with $\mathrm{NaOH}$ is the most appropriate for sheep wool and to a much greater extent for the alkaline treated wool than for the native. The reducing agent: sodium pyrosulfate and urea is the most appropriate for enzyme pre-treated samples of goat skin. Therefore, pre-treatment of animal hair samples facilitates the hydrolysis process and makes it easier to break disulfide bonds. The disadvantage of proteins, and in particular keratins, is the difference in the structure of macromolecules, which are obtained from different animal sources. Therefore, this requires a specific approach to the hydrolysis of keratin from each individual animal source.
\end{abstract}

Keywords: keratin, hydrolysates, analyzes

\section{INTRODUCTION}

Keratin is of considerable interest as a new product for use in the pharmaceutical, medical, cosmetic and biotechnology industries. Keratin is a healthy, insoluble biomaterial that can play a fundamental structural role in many biological systems (Rouse and Van Dyke, 2010). The amino acid composition changes depending on the type of keratin. The presence of a significant amount of cystine in keratin explains the presence of another type of cross-covalent bond between the main polypeptide chains, namely the disulfide bond $\mathrm{S}-\mathrm{S}$-, due to which keratin is very resistant to various physicochemical effects. Upon hydrolysis or reduction of the disulfide bond, free sulfhydryl groups - $\mathrm{SH}$ are formed. They can participate in exchange reactions with the disulfide bonds. As a result, the position of the disulfide bond in the keratin macromolecule may be altered, i.e. from transverse interchain to intrachain and vice versa (Pesheva, 1982):

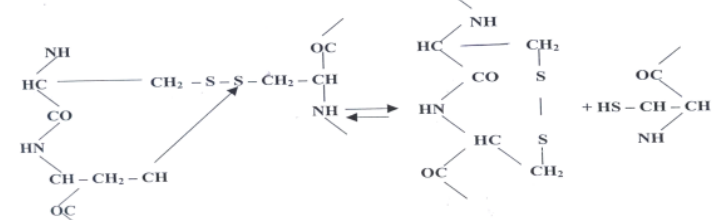

This leads to the destruction of keratin, and the degree of destruction depends on the type of pre-treatment and the conditions under which it is carried out.

Disulfide bonds are relatively resistant to acids. The bases act on all bonds in keratin. At high temperatures and high hydroxide concentrations, the peptide bonds in the major molecular chains are attacked. The disulfide bond in keratin is the most vulnerable place in its treatment with alkalis.

https://doi.org/10.24264/icams-2020.II.23 
The action of reducing agents on keratin leads to significant changes in some of its physicochemical and mechanical properties, which is used to ennoble the hair cover (Pesheva and Papazyan, 1990). The reduction of keratin is associated primarily with the destruction of disulfide bonds and the addition of new groups at the sites of released valences. The type of the newly formed group depends on the type of reducing agent and the process conditions.

The unhairing processes in leather production is carried out using sodium sulfide, which reduces the disulfide bond and results in a destruction of the hair due to the destruction of the cross-bridges between polypeptide chains of keratin as follows:

$$
\mathrm{R}-\mathrm{S}-\mathrm{S}-\mathrm{R}_{1}+2 \mathrm{Na}_{2} \mathrm{~S} \rightarrow \mathrm{R}-\mathrm{SNa}+\mathrm{R}_{1}-\mathrm{SNa}+\mathrm{Na}_{2} \mathrm{~S}_{2}
$$

Thioglycolic acid and its salts have a strong reducing effect on the disulfide bond:

$$
\mathrm{R}-\mathrm{S}-\mathrm{S}-\mathrm{R}+2 \mathrm{HS}-\mathrm{CH}_{2}-\mathrm{COOH} \rightarrow 2 \mathrm{R}-\mathrm{SH}+2 \mathrm{~S}-\mathrm{CH}_{2}-\mathrm{COOH}
$$

This reaction proceeds very rapidly in an alkaline medium, for example in $0.5 \mathrm{M}$ sodium thioglycolate at $30^{\circ} \mathrm{C}$ and $\mathrm{pH}=12$, at which the sheep's wool dissolves completely in 3 hours.

Research on the hydrolysis of keratins has been going on for many years. Some studies rely on long-term acid hydrolysis with concentrated sulfuric acid, other methods are carried out using reducing agents - thioglycolic acid, sodium cyanide, sodium sulfide, others use hydroxides - $\mathrm{NaOH}, \mathrm{KOH}, \mathrm{Ca}(\mathrm{OH}) 2$.There are also studies with the use of enzymes to denature keratin. All these methods have been known for many years, but the application of most of them is extremely difficult. During the hydrolysis, in addition to breaking both types of bonds (disulfide and peptide), the resulting structure of keratin hydrolysates is different from the structure of keratin protein (Mokrejs et al., 2011; Krejci et al., 2011; Yin et al., 2013; Cardamone et al., 2009; Cardamone, 2010; Saravanan et al., 2013; Hikima and Nonomura, 2008; Rivalcola and Martinez, 2011; Aluigi and Tonetti, 2011; Zoccola et al., 2009; Xing et al., 2011; Yang et al., 2007; Gupta et al., 2012).

The production and use of keratin hydrolysates of waste products from various industries is a topical issue. Many researchers have investigations in this field. Hydrolysis is performed under drastic conditions and aggressive reagents. The optimization of hydrolysis methods is of great importance for environmental protection, as well as for obtaining energy-saving technologies in this area.

The present study focuses on the following aspects:

- Producing keratin hydrolysates from various animal sources;

- Application of different methods for extraction;

- Comparison of the type of treatment over the degree of hydrolysis.

\section{MATERIALS AND METHODS}

In our research on the production of keratin hydrolysates, samples of goat skin coat and sheep wool were used, respectively in native form and pre-treated. Enzyme pre-treated hair cover was obtained after enzyme unhairing of goat skins. The wool, which is lime-sulphide treated, is obtained after the process of unhairing of sheepskins under certain conditions.

\section{Methods for Hydrolysis of Keratin-Containing Samples}

\section{Hydrolysis with Sodium Pyrosulphate (Metabisulphate)}

Keratin is extracted from wool by sulfitolysis with sodium metabisulfate (Aluigi and Tonetti, 2011). Approximately $5 \mathrm{~g}$ of the cleaned and conditioned fibers are treated with $100 \mathrm{~mL}$ of a solution containing urea $(8 \mathrm{M})$, sodium pyrosulphate $\left(\mathrm{Na}_{2} \mathrm{~S}_{2} \mathrm{O}_{5}\right)(0.5 \mathrm{M})$. The treatment was continued until $\mathrm{pH} 6.5$ with $\mathrm{NaOH}(5 \mathrm{~N})$ by stirring during $2 \mathrm{~h}$ at $65^{\circ} \mathrm{C}$. 
Hydrolysis with Thioglycolic Acid

The samples were hydrolysed in an aqueous solution of $0.5 \mathrm{M}$ thioglycolic acid under heating at $30^{\circ} \mathrm{C}$ for 6 hours in a water bath (Gupta et al., 2012).

Hydrolysis with Sodium Hydroxide

Cleaned and washed bird feathers are cut (Saravanan et al., 2013). They were then dissolved in $5 \% \mathrm{NaOH}$ solution for 4 hours at $40^{\circ} \mathrm{C}$. The resulting solution was dialyzed and precipitated with concentrated $\mathrm{HCl}$ at $\mathrm{pH} 4.2$.

\section{Methods for Analysis of Protein Substances}

\section{Biuret Method}

Qualitative and quantitative determination of protein can be performed by the biuret method (Jotova and Dobrev, 2000).

\section{Spectrophotometric Method}

The solutions are poured in a cuvette with a width of $10 \mathrm{~mm}$ at the wavelength $\lambda=$ $540 \mathrm{~nm}$. The apparatus used is a type JENWAY 6300 Spectrophotometer.

\section{Methods for Determination of Sulfur-Containing Amino Acids}

They are typical for proteins containing cystine and cysteine (Jotova and Dobrev, 2000).

\section{Nitroprusside Reaction}

$0.5 \mathrm{~mL}$ protein solution is mixed with $0.5 \mathrm{~mL}$ of $10 \% \mathrm{NaOH}$ solution and heated during 3 mins. After cooling, is added 2-3 drops of sodium nitroprusside. A reddishbrown color appears.

\section{Fol's Reaction}

A solution of $\mathrm{NaOH}$ was gradually added to $1 \mathrm{~mL}$ of lead acetate solution until the precipitate of lead hydroxide formed dissolved. Then add $0,5-1,0 \mathrm{~mL}$ of the tested protein solution and heat until a black color appears.

\section{Methods for Using Infrared Spectroscopy (FTIR)}

Infrared spectroscopy is a method of molecular absorption spectroscopy (Andreev, 2010). The analysis was performed using a Bruker Tensor 27 Spectrometer with a scanning speed of $10 \mathrm{kHz}$. The spectrum was recorded using an MCT detector (64 scans and $1 \mathrm{~cm}^{-1}$ resolution).

\section{EXPERIMENTAL}

Wool and goat hair samples are washed, degreased and conditioned. Each sample of the two types of hair cover is finely chopped and weighed to calculate the parameters of the obtained hydrolysates. The following methods were used:

1) hydrolysis with thioglycolic acid and urea;

2) sulphitolysis with sodium pyrosulphate and urea;

3) hydrolysis with $5 \% \mathrm{NaOH}$. 
Influence of Type of Pre-Hair Treatment from Different Types of Animal Sources on the Degree of Hydrolysis of Keratin

\section{Hydrolysis of Keratin Products from Sheep Wool}

Table 1. Results of the analysis of keratin hydrolysates from wool

\begin{tabular}{|c|c|c|c|c|}
\hline $\begin{array}{l}\text { Type of sample } \\
\text { /Wool/ }\end{array}$ & $\begin{array}{l}\text { Method of } \\
\text { hydrolysis }\end{array}$ & Biuret reaction & $\begin{array}{l}\text { Nitroprusside } \\
\text { reaction }\end{array}$ & Fol's reaction \\
\hline 1. Native wool & $\begin{array}{l}\text { thioglycolic } \\
\text { acid and urea }\end{array}$ & $\begin{array}{l}\text { Orange-yellow } \\
\text { coloring }\end{array}$ & $\begin{array}{l}\text { Does not give } \\
\text { coloring }\end{array}$ & $\begin{array}{c}\text { Black } \\
\text { coloring }\end{array}$ \\
\hline $\begin{array}{l}\text { 2. Lime-sulfide } \\
\text { pre-treated wool }\end{array}$ & $\begin{array}{l}\text { urea and } \\
\text { sodium } \\
\text { pyrosulfate }\end{array}$ & $\begin{array}{l}\text { Light violet } \\
\text { coloring } \\
A=0,167\end{array}$ & $\begin{array}{l}\text { Does not give } \\
\text { coloring }\end{array}$ & $\begin{array}{l}\text { Does not give } \\
\text { coloring }\end{array}$ \\
\hline 3. Native wool & $5 \% \mathrm{NaOH}$ & $\begin{array}{l}\text { Light violet } \\
\text { coloring } \\
\mathrm{A}=0,154\end{array}$ & $\begin{array}{l}\text { Slight brown } \\
\text { and then } \\
\text { disappears }\end{array}$ & $\begin{array}{l}\text { Does not give } \\
\text { coloring }\end{array}$ \\
\hline $\begin{array}{l}\text { 4. Lime-sulfide } \\
\text { pre-treated wool }\end{array}$ & $5 \% \mathrm{NaOH}$ & $\begin{array}{l}\text { Violet coloring } \\
\qquad \mathrm{A}=0,568\end{array}$ & Red coloring & $\begin{array}{l}\text { Does not give } \\
\text { coloring }\end{array}$ \\
\hline
\end{tabular}

In the spectra of keratin hydrolysates from the wool samples, the absorption bands for Amide III (related to the vibrational states of $\mathrm{C}-\mathrm{N}$ and N-H) and Amide I (Figures 2 , 3 and 4) were observed. Absorption band at 1000-1025 $\mathrm{cm}^{-1}$ indicates the presence of cysteine residues or sulfur-containing amino acids, and at $630-625 \mathrm{~cm}^{-1}$ indicates the presence of S-S bonds. Rupture of the disulfide bonds was observed in the lime-sulfide pre-treated wool (Fig.2 and Fig.4), as well as in the hydrolysis of the native wool with sodium hydroxide (Fig.3), in contrast to the hydrolysis of the native wool with thioglycolic acid (Fig.1). It is known that under the action of bases, hydrolysis of the disulfide bond initially occurs. FTIR observations correlate with the qualitative and quantitative methods described above.

The hydrolyzing effect of the three methods was compared, as well as the influence of the preliminary chemical treatment of the wool. Sodium hydroxide has the strongest hydrolyzing effect on both native and lime-sulfide pre-treated wool. Pre-treatment of the wool during unhairing process with calcium hydroxide and sodium sulfide significantly facilitates hydrolysis. This is due to the preliminary breaking of part of the disulfide bridges during alkaline treatment. This is confirmed by the literature. The presence of keratin protein was confirmed quantitatively and qualitatively by biuret reaction and photometrically. The infrared spectra also confirmed the extent to which disulfide and peptide bonds are depleted depending on the intensity of the adsorption bands at the respective wavelengths.

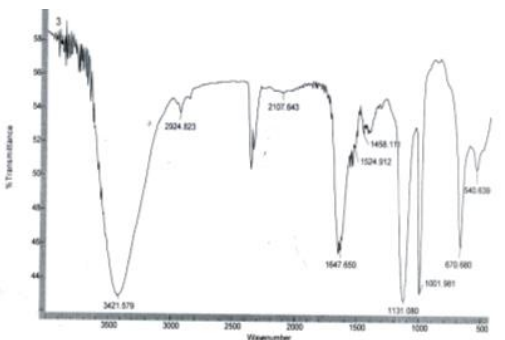

Figure 1. FTIR of native wool (thioglycolic acid and urea)

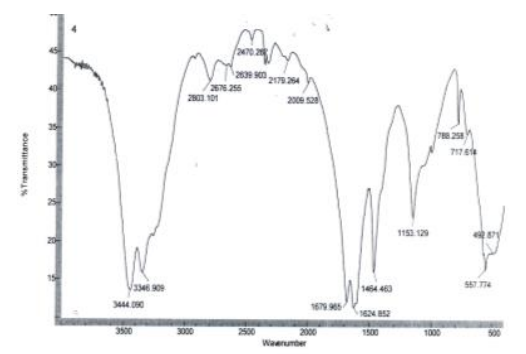

Figure 2. FTIR of lime sulfide treated wool (Na pyrosulfate and urea) 


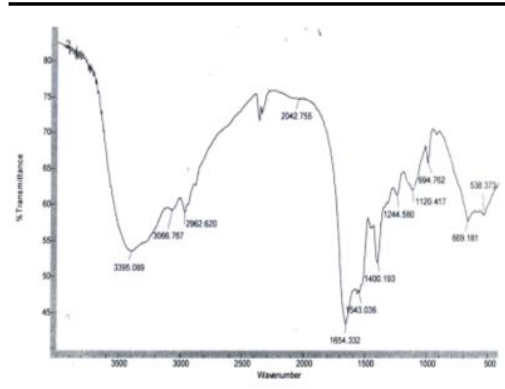

Figure 3. FTIR of native wool $(\mathrm{NaOH})$

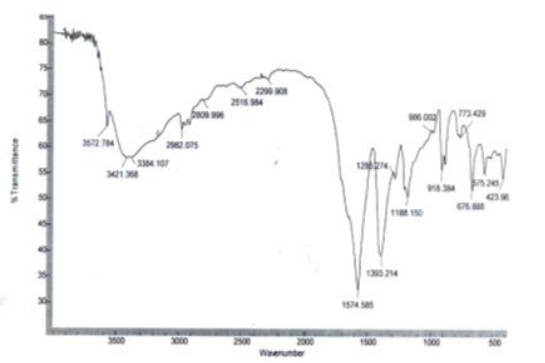

Figure 4. FTIR of lime sulfide treated wool $(\mathrm{NaOH})$

\section{Hydrolysis of Keratin Products from the Hair Cover of Goat Skins}

Table 2. Results of the analysis of keratin hydrolysates from the hair of goat skins

\begin{tabular}{llccc}
\hline $\begin{array}{l}\text { Type of sample } \\
\text { /goat hair / }\end{array}$ & \multicolumn{1}{c}{$\begin{array}{c}\text { Method of } \\
\text { hydrolysis }\end{array}$} & Biuret reaction & $\begin{array}{c}\text { Nitroprusside } \\
\text { reaction }\end{array}$ & Fol's reaction \\
\hline 1. Native & thioglycolic acid & Pale pink color & Yellow & Black \\
& and urea & $\mathrm{A}=0,045$ & coloring & coloring \\
2. Enzyme treated & urea and sodium & Violet coloring & Red coloring & $\begin{array}{c}\text { Does not give } \\
\text { coloring }\end{array}$ \\
& pyrosulfate & $\mathrm{A}=0,434$ & & Black \\
3. Native & $5 \% \mathrm{NaOH}$ & Light purple & Yellow & coloring \\
\hline
\end{tabular}

Regarding the keratin hydrolysate obtained from the enzyme pre-treated goat hair, the Fol's reaction and the Nitroprusside reaction showed that there is a rupture of the disulfide bonds and the presence of free - $\mathrm{SH}$ groups, while the results in the samples from the native hair coat showed the exact opposite, there are still disulfide bonds. This method has once again proved that pre-enzymatic treatment has played a significant role in the breaking of disulfide bridges.

The spectral analyzes show the rupture of the disulfide bonds in the sample from enzyme pre-treated goat hair (Fig.5) in contrast to the hydrolysates from native hair with thioglycolic acid (Fig.6).

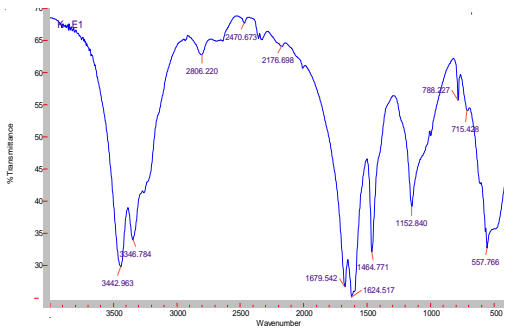

Figure 5. FTIR of enzyme pre-treated goat hair (Na pyrosulfate and urea)

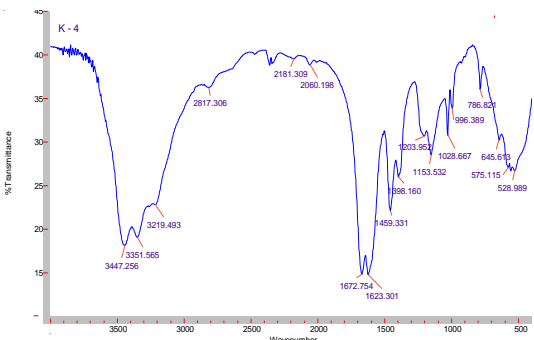

Figure 6. FTIR of native goat hair (thioglycolic acid and urea) 


\section{CONCLUSIONS}

It was found that the samples from one and the same animal source show very different properties and different degrees of hydrolysis. The highest degree of hydrolysis was achieved for the pre-treated samples. It was proved that the method of hydrolysis with $\mathrm{NaOH}$ is the most appropriate for sheep wool and to a much greater extent for the alkaline treated wool than for the native. The reducing agent: sodium pyrosulfate and urea is the most appropriate for enzyme pre-treated samples of goat hair. Therefore, pre-treatment of animal hair samples facilitates the hydrolysis process and makes it easier to break disulfide bonds. The data from the FTIR analysis completely correlate with the quantitative and qualitative analyzes and show the degree of rupture of the disulfide bonds depending on the intensity of the adsorption bands.

It was observed that the hydrolysis processes proceed more easily in sheep wool samples than in goat hair samples. Lime sulfide treatment is a more suitable option for weakening peptide and disulfide bonds, which is a widespread method in the leather industry for unhairing. Therefore, waste from tanneries is a suitable material for the hydrolysis of keratin.

\section{REFERENCES}

Aluigi, A. and Tonetti, C. (2011), “Adsorption of cooper (II) ions by keratin / PA6 blend nanofibers", Eur. Polym. J., (47), 1756-1764, https://doi.org/10.1016/j.eurpolymj.2011.06.009.

Andreev, G. (2010), Molecular spectroscopy, University ed., p.72 (in Bulgarian)

Cardamone, J. (2010), "Investigation the microstructure of keratin extracted from wool: Peptide sequence (MALDI-TOF/TOF) and protein conformation (FTIR)", J. Mol. Structure, 969, 97-105, https://doi.org/10.1016/j.molstruc.2010.01.048.

Cardamone, J., Nunez, A., Garcia, R. and Ramos, M. (2009), “Characterizing Wool Keratin”, Research Letter in Mater. Sci., https://doi.org/10.1155/2009/147175.

Gupta, A., Kamarudin, N., Kee, C. and Yunus, R. (2012), "Extraction of Keratin Protein from Chicken Feather, J. Chem. Chem. Eng., 6, 732-737.

Hikima, T. and Nonomura, Y. (2008), "Powderization of Wool Keratin by Alkali Hydrolysis in Higher Alcohol /Water Binary Systems", Chemistry Letters, 37(3), 338-339, https://doi.org/10.1246/cl.2008.338.

Jotova, L. and Dobrev, I. (2000), Practicum in biochemistry part I, Diagnosis Press (in Bulgarian).

Krejci, O., Mokrejs, P. and Sukop, S. (2011), "Preparation and Characterization of Keratin Hydrolysates", Math. Methods and Tech. in Eng. and Env. Sci., ISBN: 978-1-61804-046-6, p.308.

Mokrejs, P., Krejci, O. and Svoboda, P. (2011), "Producing Keratin Hydrolysates from Sheep Wool", Oriental J. of Chemistry, 27(4), 1303-1309.

Pesheva, M. (1982), Chemistry and Physics of raw leather and tanning substances, Sofia (in Bulgarian).

Pesheva, M. and Papazyan, L. (1990), Fundamentals of leather and fur production, Sofia (in Bulgarian).

Rivalcola, V. and Martinez, A. (2011), "Removal of Hexavalent Chromium from Water by Polyurethane/ Keratin Hybrid Membranes", Water Air Soil Pollut. J., 218, 557-571, https://doi.org/10.1007/s11270-010-0668-6.

Rouse, J. and Van Dyke, M. (2010), “A Review of Keratin-Based Materials for Biomedical Applications Material J., 3, 999-1014, https://doi.org/10.3390/ma3020999.

Saravanan, S., Sameera, D., Moorthi, A. and Sevamurugan, N. (2013), "Chitosan scaffolds containing chicken keratin nanoparticles for bone tissue engineering”, Inter. J. Biol. Macromol., 62, 481-486, https://doi.org/10.1016/j.ijbiomac.2013.09.034.

Xing, Z., Yuan, J., Chae, W. and Kang, I., (2011), "Keratin Nanofibres as a Biomaterial”, 2010 Inter. Conf. on Nanotechnology and Biosensors IPCBEE, 2, 120-124.

Yang, X., Lin, Z. and Shuxun, C. (2007), "Effect of concentration of wool keratin on the rebuilding of disulfur bond", Chinese Science Bulletin, 52(20), 2876-2879, https://doi.org/10.1007/s11434-007-0418-3.

Yin, X., Li, F., He, Y., Wang, Y. and Wang, R. (2013), "Study of effective extraction of chicken feather keratins and their films for controlling drug release", Biomaterials Sci. J., 5, 528-536, https://doi.org/10.1039/c3bm00158j.

Zoccola, M., Aluigi, A. and Tonin, C. (2009), "Characterization of keratin biomass from butchery and wool industry wastes", J. Mol. Structure, 938, 35-40, https://doi.org/10.1016/j.molstruc.2009.08.036. 